American Journal of Environmental Sciences 7 (2): 119-124, 2011

ISSN 1553-345X

(C) 2010 Science Publications

\title{
A Decision Making Tool for Hazardous Waste Landfill Site Selection
}

\author{
P. Pandiyan, A. Murugesan, T. Vidhyadevi, S. Dineshkirupha, \\ M. Pulikesi and S. Sivanesan \\ Department of Chemical Engineering, A. C. Tech, Anna University, Chennai-600 025, India
}

\begin{abstract}
Problem statement: Continuous global environmental crisis and degradation has been a challenge for the sustainability of living on earth. This threat was posed by industrialization, high products need, urbanization and population growth activities. As a result, the hazardous waste generation has tremendously increased. Approach: Landfill was one of the positive approaches to handle hazardous waste generated in great quantity. The appropriate selection of landfill site played a major role to remediate the hazardous waste materials. Attributes to be considered for decision-making were selected based on literature, observations with weightage assigned to each attribute following the pair wise comparison method and sensitivity index on a scale of 0 to 1 based on attribute measurement. The attributes were then grouped and ranked following Delphi approach. Results: In environmental assessment, field based study of three landfill sites such as Melakottaiyur, Pachaiyankuppam and Gummidipoondi in Tamil Nadu, India were selected and the sites scored a Risk Index (RI) of 298.75, 369.05 and 408.25 respectively. In economical assessment, economic viability related attributes were analyzed and the three landfill site such as Pachaiyankuppam, Melakottaiyur and Gummidipoondi scored a RI of 86.1, 94.3 and 131.5 respectively. Conclusion/Recommendations: In environmental assessment the landfill sites were shortlisted. In order to achieve economic sustainability of the landfill, economic viability related attributes has to be analyzed with high priority and weightage in economical assessment.
\end{abstract}

Key words: Hazardous waste, landfill site selection, attributed score, decision-making, sensitivity index, Delphi approach, environmental assessment, economic sustainability

\section{INTRODUCTION}

Hazardous waste management is the most challenging and costly area of modern environmental management of waste disposal and reduction of wastes in the environment. The open dumps method is mainly practised by many countries to dispose the hazardous waste materials. In managing and planning the hazardous waste systems, multiple goals, such as socioeconomic and environmental control goals have to be properly addressed (Alshammari et al., 2008).Thus, a preliminary screening exercise based on the field observations and various site attributes is required to be carried to avoid huge costs involved in detailed environmental assessment (Tchobanoglous and Kreith, 2002).Few more aspects are also involved pertaining to the ideal site selection for TSDF, based on its location significance. Therefore, proper landfill site selection is a critical issue in the urban planning process because of its enormous impact on the economy, ecology and the environment and health of the region (Chang et al., 2008).
The principle concern in any landfill site selection is environmental protection and public health consideration. Therefore, all our initial efforts will go towards the selection of an appropriate site that will minimize potential environmental impacts and provide a sound basis for effective management. There are numerous literature reports were analysed the landfill site selection by various researchers such as Multi Criteria Decision-Making (MCDM) model (Alumur and Kara, 2007), spatial multiple criteria analysis method (Kontos et al., 2003) and Geographic Information System (GIS) (Monprapussorn et al., 2009). Chang et al., (2008) were used combined GIS and a convoluted multi-criteria decision making process to select a landfill site. Guiqin et al. (2009) used spatial information technologies and AHP for landfill site selection in Beijing, China and a comprehensive Environmental Assessment (EA) for the selection of hazardous waste landfill site. A risk based approach to solid waste management using a Landfill Location Criteria Calculator (LLCC). The efforts we invest in bringing out the outcome using afore methods are

Corresponding Author: S. Sivanesan, Department of Chemical Engineering, A. C. Tech, Anna University, Chennai-600 025, India 
expensive compared to Delphi approach.In addition to that there are several advantages to the Delphi approach. One of the most significant is its versatility. The approach can be used in a wide range of areas, e.g., government planning, business and industry predictions, Environmental studies volunteer group decisions.

This study presents an integrated economical and environmental based approach for developing a decision-making tool for hazardous waste landfill site selection. The approach provides higher priority to economic viability of the site. Two phases were used to select the landfill site, in the first phase, the sites were shortlisted based on the environmental aspects and in the second phase, the short listed sites were economically analysed following altered Delphi approach (Delbecq et al., 1975).

\section{MATERIALS AND METHODS}

Site selection: There are two goals of developing a centralized hazardous waste treatment facility such as, environmentally sound disposal system and economic sustainability of the facility. The technical aspects of providing an environmentally sound treatment/disposal system are probably more straightforward than the commercial issues since they are dictated by regulations; however, they influence economic sustainability directly. Economic sustainability is the driving force for any commercial entity. It is the sole reason for expenditure of capital by the investor; without it, the venture will fail. Krishna and Babu (1999) discussed the various operations effecting the site selection.

So far, the landfill sites are selected based on environmental and technical aspects with minimal consideration of the economic feasibility of the project. Due to this conventional method of selection, the operation and maintenances of the landfill site becomes a burden to the operator and to the waste generator in terms of economic concern. Moreover, the project may fail due to economic non-viability. Saxena and Bhardwaj (2003) have reported an approach to assess the hazard potential rating prior to developing an upgradation plan for existing municipal solid waste dumpsite. According to the model proposed by Lakshmi the landfill site selection can be segmented into phase 1 that covers environmental related attributes and phase 2, which covers critical economic related attribute such as transport. Three landfill sites were taken for the study located in Tamilnadu, India.
Site sensitivity indices method: The site sensitivity attributes were selected based on the literature, data obtained through observation of activities and investigations in and around a few dumpsites, consultation with experts on the contribution of the attributes to pollution, health risks and social impacts. The selection of the attributes was done based on the inputs of an expert panel consisting of researchers (40\%), academicians (12\%) municipal officers (15\%), regulators (23\%) and consultants (10\%). Questionnaires were sent to experts in solid waste management in Asia. The panel members were requested to select the parameters to be considered for developing the tool and to allot relative importance in terms of significance numbers ranging from 1 to 10 . The attributes were then grouped under the below seven categories and ranked following the Delphi approach.

- Accessibility related

- Receptor related

- Ecological related

- Sociological related

- Waste management practice related

- Climatologically related

- Geological related

The top ranking 32 parameters were short-listed and weightage of attributes (Wi) were assigned based on the pair wise comparison method (Canter, 1996) such that the total weightage was 1000. Each attribute was measured in terms of a sensitivity index ( $\mathrm{Si}$ ) on scale of $0-1(0.0-0.25,0.25-0.5,0.5-0.75,0.75-1.0)$ to facilitate computation of cumulative scores called Risk Index (RI) that can be used for short listing of landfill sites. While " 0 ” indicated no or very less potential hazard. " 1 " indicated the highest potential hazard. Allotment of sensitivity indices for the selected parameters was made following earlier studies (Saxena and Bhardwaj, 2003).

The RI of the site was calculated using the following formula:

$\mathrm{RI}=\sum_{\mathrm{i}=1}^{\mathrm{n}} \mathrm{WiSi}$

Where:

$\mathrm{Wi}=$ Weightage of the $\mathrm{i}^{\text {th }}$ variable ranging from 0 1000

$\mathrm{Si}=$ Sensitive index of the $\mathrm{i}^{\text {th }}$ variable ranging from 0 1

RI = Risk Index variable from 0-1000 
Am. J. Environ. Sci., 7 (2): 119-124, 2011

Based on the field data available, this attribute can be graded on the four level scales for the particular site. A total of 1000 points are divided among the seven criteria (Table 1) of attributes at $60,250,305,110,85$, 40 and 150 respectively using Delphi approach. The value of the sensitivity index multiplied by the corresponding weightage would give the attributed score for each attribute. In the same way, score for all the attributes can be calculated and final attributed score for the site is obtained. This score is compared with the similar scores of the other sites available and all the sites are ranked as per the scores with the least score site given the top ranking. The total scores (out of 1000) can be interpreted in terms of the sensitivity of the site as follows:

- Score below 300: Very low sensitivity

- Score between 300-450: Low sensitivity

- Score between 450-600: Moderate sensitivity

- Score between 600-750: High sensitivity

- Score above 750: Very high sensitivity
For example, an attribute, distance to nearest drinking water source, carrying a weightage of 55 points, can be graded based on the following four options:

- Greater than $5000 \mathrm{~m}$ (sensitivity scale: $0.0-0.25$ )

- $\quad 2500-5000 \mathrm{~m}$ (sensitivity scale: $0.25-0.5$ )

- $\quad 1000-2500 \mathrm{~m}$ (sensitivity scale: $0.5-0.75$ )

- Less than $1000 \mathrm{~m}$ (sensitivity scale: $0.75-1.0$ )

\section{RESULTS}

Phase 1: Environmental related attributes: The results of the validation exercise of the tool done for Melakottaiyur, Pachaiyankuppam and Gummidipoondi landfill sites in Tamilnadu, India presented in Table 1 show that the landfill sites scored a RI of 298.75, 369.05 and 408.25 respectively. The classification has been done in line with the criteria recommended by Ministry of Environment and Forests, Government of India, for classification of risk potential of abandoned hazardous waste dumps. When consider the economic attribute weightage the above ranking may change.

Table 1: Attribute measurements for environmental related attributes

\begin{tabular}{|c|c|c|c|c|c|c|c|c|c|c|}
\hline \multirow[b]{3}{*}{ Attribute } & \multicolumn{4}{|c|}{ Melakottaiyur landfill site } & \multicolumn{3}{|c|}{ Gummidipoondi landfill site } & \multicolumn{3}{|c|}{ Pachaiyankuppam landfill site } \\
\hline & \multirow{2}{*}{$\begin{array}{l}\text { Attribute } \\
\text { weightage }\end{array}$} & \multirow{2}{*}{$\begin{array}{ll}\text { Attribute } & \mathrm{S} \\
\text { e measurement } \mathrm{i}\end{array}$} & \multirow{2}{*}{\multicolumn{2}{|c|}{$\begin{array}{l}\text { Sensitivity Attribute } \\
\text { index score }\end{array}$}} & \multirow{2}{*}{$\begin{array}{l}\text { e Attribute } \\
\text { measurement }\end{array}$} & \multirow{2}{*}{$\begin{array}{l}\text { Sensitivity } \\
\text { index }\end{array}$} & \multirow{2}{*}{$\begin{array}{l}\text { Attribute } \\
\text { score }\end{array}$} & \multirow{2}{*}{\multicolumn{2}{|c|}{$\begin{array}{l}\text { Attribute Sensitivity } \\
\text { measurement index }\end{array}$}} & \multirow{2}{*}{$\begin{array}{l}\text { Attribute } \\
\text { score }\end{array}$} \\
\hline & & & & & & & & & & \\
\hline Accessibility related & & & & & & & & & & \\
\hline Type of road & 25 & Local road & 0.50 & 12.5 & $\begin{array}{l}\text { National } \\
\text { highway }\end{array}$ & 1 & 25 & Local road & 0.5 & 12.5 \\
\hline $\begin{array}{l}\text { Distance from } \\
\text { collection point }\end{array}$ & 35 & $>25 \mathrm{~km}$ & 0.80 & 28 & $>50 \mathrm{~km}$ & 1 & 35 & $>50 \mathrm{~km}$ & 1 & 35 \\
\hline Total & 60 & & & 40.5 & & & 60 & & & 47.5 \\
\hline \multicolumn{11}{|l|}{ Receptor related } \\
\hline Population within 500 m & 50 & $0-100$ & 0.10 & 5 & $100-500$ & 0.5 & 25 & $100-500$ & 0.5 & 25 \\
\hline $\begin{array}{l}\text { Distance to nearest drinking } \\
\text { water source }\end{array}$ & 55 & $1000-2500 \mathrm{~m}$ & 0.55 & 30.25 & $>5000 \mathrm{~m}$ & 0.25 & 13.75 & $>5000 \mathrm{~m}$ & 0.2 & 11 \\
\hline $\begin{array}{l}\text { Use of site by near by } \\
\text { residence }\end{array}$ & 25 & Not used & 0.00 & 0 & Not used & 0 & 0 & Not used & 0 & 0 \\
\hline Distance to nearest building & 15 & $500-1500 \mathrm{~m}$ & 0.50 & 7.5 & 500-1500 m & 0.5 & 7.5 & $1000-1500$ & 0.3 & 4.5 \\
\hline Landuse/zoning & 35 & $\begin{array}{l}\text { Completely } \\
\text { remote (zoning } \\
\text { not applicable) }\end{array}$ & 000 & $\begin{array}{l}0 \\
\text { area }\end{array}$ & Industrial 0.5 & $\begin{array}{l}17.5 \\
\text { area }\end{array}$ & Industrial & 0.5 & 17.5 & \\
\hline $\begin{array}{l}\text { Decrease in property value } \\
\text { with respect to distance }\end{array}$ & 15 & $>5000 \mathrm{~m}$ & 0.05 & 0.75 & $<500 \mathrm{~m}$ & 0.75 & 11.25 & $<500 \mathrm{~m}$ & 0.75 & 11.25 \\
\hline $\begin{array}{l}\text { Public utility facility } \\
\text { within } 2 \mathrm{kms}\end{array}$ & 25 & 2 industries & 0.05 & 1.25 & $\begin{array}{l}>10 \\
\text { industries }\end{array}$ & 0.5 & 12.5 & 2 industries & 1.25 & 1.25 \\
\hline Public acceptability & 30 & $\begin{array}{l}\text { Acceptance } \\
\text { with } \\
\text { suggestions }\end{array}$ & 0.300 & 9 & Not accepted & 0.75 & $\begin{array}{l}22.5 \\
\text { concern }\end{array}$ & No public & 0.1 & 3 \\
\hline Total & 250 & & 53.75 & & & 110 & & & 73.50 & \\
\hline \multicolumn{11}{|l|}{ Ecological related } \\
\hline Critical environment & 45 & $\begin{array}{l}\text { Not a critical } \\
\text { environment }\end{array}$ & 0.05 & 2.25 & $\begin{array}{l}\text { Critical } \\
\text { environment }\end{array}$ & 0.75 & 33.75 & $\begin{array}{l}\text { Critical } \\
\text { environment }\end{array}$ & $\mathrm{nt}^{0.75}$ & 33.75 \\
\hline $\begin{array}{l}\text { Distance to nearest } \\
\text { surface water }\end{array}$ & 55 & $<500 \mathrm{~m}$ & 0.75 & 41.25 & $1500-8000 \mathrm{~m}$ & 0.5 & 27.5 & $3000-5000 m$ & m 0.3 & 16.5 \\
\hline
\end{tabular}


Am. J. Environ. Sci., 7 (2): 119-124, 2011

\begin{tabular}{|c|c|c|c|c|c|c|c|c|c|c|}
\hline Depth to ground water & 65 & $>30 \mathrm{~m}$ & 0 & 0 & $>30 \mathrm{~m}$ & 0 & 0 & $<30$ & 0.5 & 32.5 \\
\hline Contamination & 35 & $\begin{array}{l}\text { No } \\
\text { contamination }\end{array}$ & 0.75 & 26.25 & $\begin{array}{l}\text { No } \\
\text { contamination }\end{array}$ & 0.75 & $\begin{array}{l}26.25 \\
\text { contamination }\end{array}$ & No & 0.75 & 26.50 \\
\hline Water quality & 40 & Potable & 0.5 & 20 & Potable & 0.5 & 20 & Potable & 0.5 & 20 \\
\hline Air quality & 35 & $\begin{array}{l}\text { Conforming } \\
\text { to residential } \\
\text { standards }\end{array}$ & 0.75 & 26.25 & $\begin{array}{l}\text { Not } \\
\text { conforming } \\
\text { to residential }\end{array}$ & 0.25 & 8.75 & $\begin{array}{l}\text { Not } \\
\text { Conforming } \\
\text { to residential } \\
\text { standards }\end{array}$ & 0.25 & 8.75 \\
\hline Soil quality & 30 & $\begin{array}{l}\text { No } \\
\text { contamination }\end{array}$ & 0.8 & 24 & $\begin{array}{l}\text { Medium } \\
\text { contamination }\end{array}$ & 0.75 & $\begin{array}{l}22.5 \\
\text { contamination }\end{array}$ & No & 0.8 & 24 \\
\hline Total & 305 & & & 140 & & & 138.75 & & & 162.25 \\
\hline \multicolumn{11}{|l|}{ Sociological related } \\
\hline Health & 40 & Moderate & 0.25 & 10 & Moderate & 0.25 & 10 & Moderate & 0.25 & 10 \\
\hline Job opportunities & 20 & Moderate & 0.3 & 6 & High & 0.8 & 16 & Moderate & 0.3 & 6 \\
\hline Odour & 30 & No odour & 0.1 & 3 & Low odour & 0.25 & 7.5 & Low odour & 0.25 & 7.5 \\
\hline Vision & 20 & Not visible & 0 & 0 & Visible & 0.25 & 5 & Visible & 0.25 & 5 \\
\hline Total & 110 & & & 19 & & & 38.5 & & & 28.5 \\
\hline \multicolumn{11}{|l|}{$\begin{array}{l}\text { Waste management } \\
\text { practice related }\end{array}$} \\
\hline Waste quantity/day & 45 & $250-500$ & 0.25 & 11.25 & $250-500$ & 0.25 & 11.25 & $<250$ & 0 & 0 \\
\hline Life of site & 40 & $>20$ years & 0 & 0 & $<10$ years & 0.75 & 30 & $<10$ years & 0.75 & 30 \\
\hline Total & 85 & & & 11.25 & & & 41.25 & & & 30 \\
\hline \multicolumn{11}{|l|}{ Climatologically related } \\
\hline $\begin{array}{l}\text { Prescription effectiveness } \\
\text { index }\end{array}$ & 25 & $<31$ & 0.1 & 2.5 & $>31$ & 0.25 & 6.25 & $<31$ & 0.1 & 2.5 \\
\hline $\begin{array}{l}\text { Climatic features } \\
\text { contributing to air pollution }\end{array}$ & 15 & No problem & 0 & 0 & Problem & 0.25 & 3.75 & Problem & 0.25 & 3.75 \\
\hline Total & 40 & & & 2.5 & & & 10 & & & 5.80 \\
\hline \multicolumn{11}{|l|}{ Geological related } \\
\hline Soil permeability & 35 & $\begin{array}{l}>1 \times 10^{-7} \\
\mathrm{~cm} / \mathrm{sec}\end{array}$ & 0.05 & 1.75 & $\begin{array}{l}>1 \times 10^{-7} \\
\mathrm{~cm} / \mathrm{sec}\end{array}$ & 0.05 & 1.75 & Moderate & 0.05 & 1.75 \\
\hline Depth of rock & 20 & $3-10 m$ & 0.5 & 10 & $>30 \mathrm{~m}$ & 0 & 0 & 3 to $10 \mathrm{~m}$ & 0.5 & 10 \\
\hline $\begin{array}{l}\text { Susceptibility to } \\
\text { erosion and run-off }\end{array}$ & 15 & $\begin{array}{l}\text { Not } \\
\text { susceptible }\end{array}$ & 0.05 & 0.75 & $\begin{array}{l}\text { Not } \\
\text { susceptible }\end{array}$ & 0.05 & 0.75 & $\begin{array}{l}\text { Not } \\
\text { susceptible }\end{array}$ & 0.05 & 0.75 \\
\hline $\begin{array}{l}\text { Physical characteristics } \\
\text { of rock }\end{array}$ & 15 & Massive & 0.10 & 1.5 & No & 0 & 0 & Massive & 0.10 & 1.5 \\
\hline Depth of soil layer & 30 & $3 \mathrm{~m}$ & 0.3 & 9 & $>15 \mathrm{~m}$ & 0.05 & 1.5 & $>15 \mathrm{~m}$ & 0.05 & 1.5 \\
\hline Slope pattern & 15 & $1-2 \%$ & 0.25 & 3.75 & No slope & 0.05 & 0.75 & No slope & 0.05 & 0.75 \\
\hline Seismicity & 20 & Zone II & 0.25 & & Zone III & 0.25 & & Zone II & 0.25 & \\
\hline Total & 150 & & & 31.75 & & & 9.75 & & & 21.25 \\
\hline Grand total(RI) & 1000 & & & 298.75 & & & 408.25 & & & 369.05 \\
\hline
\end{tabular}

Phase 2: Economical viability related attributes: In phase-2 assessment, economical related attributes such as quantity of waste, distance from collection point and average transportation cost were analyzed. These attributes strongly affects the economic sustainability of the landfill sites. After the sites were shortlisted according to environmental factors, these economic attributes can be taken into consideration for the selection of landfill sites. The weightage of attributes were increased based on the pair wise comparison method and considering the opinion of financial analyst, the total weightage has been figured to 220 .

\section{DISCUSSION}

Quantity of waste: Quantity of waste having considerable effect on life of site in turn it affects the economic viability of the site. The landfill site should be selected in the area where large number of industries available. Then only the revenue to the landfill operator will be good. The hazardous waste generating industries such as electroplating, chemical, petrochemical, service stations, textile processing and engineering type of industries are located around the sites. It is estimated in Pachaiyankuppam waste management quantity is around 100 tons/day. In case of Gummidipoondi and Melakottaiyur the waste management quantity lies between 250-500 tons/day.

Distance from collection point: The distance between collection point and landfill site is having direct impact on transportation cost. The transportation cost of hazardous waste should be paid by waste generating industry, which is included with the treatment cost. In addition, the spillage risk will be reduced if the distance is less. In this study seven waste collection headquarters such as Chennai, Kancheepuram, Thiruvallur, Vellore, Thiruvannnamalai, Villupuram and Cuddalore located in Tamilnadu, India are taken into consideration. 
Am. J. Environ. Sci., 7 (2): 119-124, 2011

Table 2: Attribute measurements for economic viability related attributes

\begin{tabular}{|c|c|c|c|c|c|c|c|c|c|c|}
\hline \multirow[b]{2}{*}{ Attribute } & \multirow[b]{2}{*}{$\begin{array}{l}\text { Attribute } \\
\text { weightage }\end{array}$} & \multicolumn{3}{|c|}{ Melakottaiyur landfill site } & \multicolumn{3}{|c|}{ Gummidipoondi landfill site } & \multicolumn{3}{|c|}{ Pachaiyankuppam landfill site } \\
\hline & & $\begin{array}{l}\text { Attribute } \\
\text { e measurement }\end{array}$ & $\begin{array}{l}\text { Sensitivity } \\
\text { index }\end{array}$ & $\begin{array}{l}\text { Attribute } \\
\text { score }\end{array}$ & $\begin{array}{l}\text { Attribute } \\
\text { measurement }\end{array}$ & $\begin{array}{l}\text { Sensitivity } \\
\text { index }\end{array}$ & $\begin{array}{l}\text { Attribute } \\
\text { score }\end{array}$ & $\begin{array}{l}\text { Attribute } \\
\text { measurement }\end{array}$ & $\begin{array}{l}\text { Sensitivity } \\
\text { index }\end{array}$ & $\begin{array}{l}\text { Attribute } \\
\text { score }\end{array}$ \\
\hline $\begin{array}{l}\text { Average transportation } \\
\text { Cost(Rs) }\end{array}$ & 90 & 455.75 & 0.32 & 28.8 & 682.02 & 0.60 & 54 & 435.34 & 0.29 & 26.1 \\
\hline Quantity of waste/day(MT) & 70 & $250-500$ & 0.25 & 17.5 & $250-500$ & 0.25 & 17.5 & $<250$ & 0 & 0 \\
\hline $\begin{array}{l}\text { Distance from collection } \\
\text { point }(\mathrm{Km})\end{array}$ & 60 & $>25$ & 0.8 & 48 & $>50$ & 1 & 60 & $>50$ & 1 & 60 \\
\hline Risk index & 220 & & & 94.3 & & & 131.5 & & & 86.1 \\
\hline
\end{tabular}

The distance between Melakottaiyur site and the collection point is greater than $25 \mathrm{~km}$ whereas the distance from Gummidipoondi and pachaiyankuppam site to the collection point is greater than $50 \mathrm{~km}$.

Average transportation cost: Based on field study average transport cost per metric ton has been calculated as Rs 435.34, 455.75 and 682.02 for Pachaiyankuppam, Melakottaiyur and Gummidipoondi respectively.

Note: Transport cost has taken as $4 \mathrm{Rs} / \mathrm{ton} / \mathrm{km}$ for calculation.

The identified project cost based on transportation indicates that Pachaiyankuppam landfill is having less sensitivity indices of 0.29 (Table 2). The modest transportation cost of Melakottaiyur landfill is more or less subjected to sensitivity of nearly 0.32 . The transportation cost of Gummidipoondi landfill is very high with a sensitivity of 0.6 , which eventually enhances the economics of project cost (Table 2).

\section{CONCLUSION}

In this study, the values used for Melakottaiyur and Gummidipoondi sites are real time and values of Pachaiyankuppam site are simulated in order to differentiate from the conventional method. By the end of first phase, the sites were shortlisted in the following order as Melakottaiyur, Pachaiyankuppam and Gummidipoondi. We propose that in second phase, the economic viability related attributes should be analysed with high priority and weightage. The economic viability related attributes are quantity of waste, distance from collection point, average transportation cost, life of site, investment on infrastructure, land cost and cost of treatment. Each of these attributes has major effect on the main goal of the business venture, that of economic sustainability; therefore, each factor is carefully managed and by the end of the second phase, the sites are ranked in the following order as Pachaiyankuppam, Melakottaiyur and Gummidipoondi.
Development of economical viability based decision-making tool is an attempt to provide guidance to Government and other implementing authorities for quick decision making for prioritizing actions related to hazardous waste landfill site selection. Detailed investigations and regulatory approval may be required as per the respective national or local legislations. Further work to refine the approach with inputs from more experts in the region and validation by application to different landfill sites in Asia is in progress.

\section{REFERENCES}

Alumur, S. and B.Y. Kara, 2007. A new model for the hazardous waste location-routing problem. Comput. Operat. Res., 34: 1406-1423. DOI: 10.1016/j.cor.2005.06.012

Alshammari, J.S., F.K. Gad, A.A.M. Elgibaly and A.R. Khan, 2008. A typical case study: solid waste management in petroleum refineries. Am. J. Environ. Sci., 4: 397-405. DOI: 10.3844/ajessp.2008.397.405

Canter, L.W., 1996. Environmental Impact Assessment, 2nd Edition, McGraw-Hill, USA., ISBN-10: 0070097674, pp: 660.

Chang, N.B., G.Parvathinathan and J.B. Breeden, 2008. Combining GIS with fuzzy Multicriteria decisionmaking for landfill siting in a fast-growing urban region. J. Environ. Manage., 87: 139-153. DOI: 10.1016/j.jenvman.2007.01.011

Delbecq, A.L., A.H. Van de Ven and D.H Gustafson, 1975. Group Techniques for Program Planning: A Guide to Nominal Group and Delphi. 1st Edn., Scott, Foresman, USA., ISBN-10: 0673075915, pp: 174.

Guiqin, W., L. Qin, L. Guoxue and L. Chen, 2009. Landfill site selection using spatial information technologies and AHP: A case study in Beijing, China. J. Environ. Manage., 90: 2414-2421. DOI: 10.1016/j.jenvman.2008.12.008

Kontos, T.D., D.P. Komilis and C.R. Halvadakis, 2003. Siting MSW landfills on Lesvos Island with a GIS-based methodology. Waste Manage. Res., 21: 262-277. PMID: 12870646 
Krishna, V.R. and B.V. Babu, 1999. Site selection criteria for hazardous waste treatment, storage and disposal facility. Birla Institute of Technology \& Science. pilani.ac.in/ bvbabu/TsdfVidisha99.pdf

Monprapussorn, S., D. Thaitakoo and D.J. Watts, 2009. Multi criteria decision analysis and geographic information system framework for hazardous waste transport sustainability. J. Applied Sci., 9: 268-277.
Saxena, A.K. and K.D. Bhardwaj, 2003. Environmental Assessment and up-gradation plan for existing municipal waste disposal site-A case study. Proceedings of the Workshop on Sustainable Landfill Management, Dec. 3-5, Chennai, India, pp: 287-301.

Tchobanoglous, G. and F. Kreith, 2002. Handbook of Solid Waste Management. 2nd Edn., McGraw Hill Professional, USA., ISBN-10: 0071356231, pp: 950. 